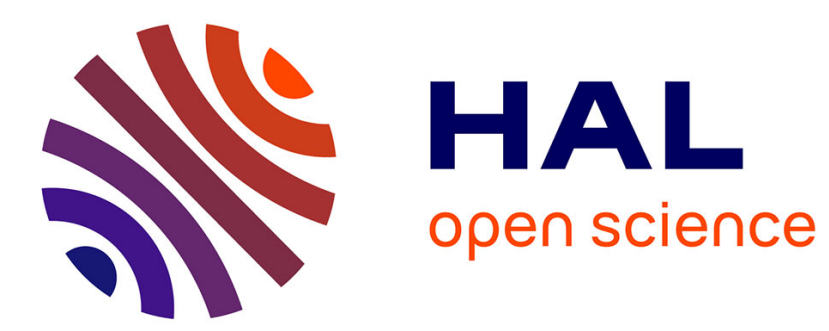

\title{
Liquidity Regulation and Bank Lending
}

Foly Ananou, Amine Tarazi, John O.S Wilson

\section{To cite this version:}

Foly Ananou, Amine Tarazi, John O.S Wilson. Liquidity Regulation and Bank Lending. 2020. hal$02516749 \mathrm{v} 2$

\section{HAL Id: hal-02516749 \\ https://hal-unilim.archives-ouvertes.fr/hal-02516749v2}

Preprint submitted on 14 Oct 2020

HAL is a multi-disciplinary open access archive for the deposit and dissemination of scientific research documents, whether they are published or not. The documents may come from teaching and research institutions in France or abroad, or from public or private research centers.
L'archive ouverte pluridisciplinaire HAL, est destinée au dépôt et à la diffusion de documents scientifiques de niveau recherche, publiés ou non, émanant des établissements d'enseignement et de recherche français ou étrangers, des laboratoires publics ou privés. 


\title{
Liquidity Regulation and Bank Lending
}

\author{
Foly Ananou $^{\mathrm{a}, 1}$, Amine Tarazi $^{\mathrm{a}, \mathrm{b}}$, John O.S. Wilson $^{\mathrm{c}}$ \\ ${ }^{\text {a } U n i v e r s i t e ́ ~ d e ~ L i m o g e s, ~ L A P E, ~} 5$ rue Félix Eboué, 87031 Limoges Cedex 1, France \\ ${ }^{\mathrm{b}}$ Institut Universitaire de France (IUF), 1 rue Descartes, 75231 Paris Cedex 05, France \\ ${ }^{\mathrm{c}}$ University of St Andrews, Centre for Responsible Banking \& Finance, Gateway Building, \\ St Andrews, Fife KY16 9RJ, UK
}

This version: June 19, 2020

\begin{abstract}
Bank liquidity shortages during the global financial crisis of 2007-2009 led to the introduction of liquidity regulations, the impact of which has attracted the attention of academics and policymakers. In this paper, we investigate the impact of liquidity regulation on bank lending. As a setting, we use the Netherlands, where a Liquidity Balance Rule (LBR) was introduced in 2003. The LBR was imposed on Dutch banks only and did not apply to other banks operating elsewhere within the Eurozone. Using this differential regulatory treatment to overcome identification concerns and a difference-in-differences approach, we find that stricter liquidity requirements did not reduce the lending of Dutch banks relative to other banks not subject to the provisions of the LBR. However, the LBR did lead Dutch banks to modify the structure of loan portfolios by increasing corporate lending and reducing mortgage lending relative to banks not subject to the LBR. Dutch banks also experienced a significant increase in deposits and issued more equity relative to counterparts not subject to the liquidity requirements. Overall, our results have obvious relevance for policymakers tasked with monitoring the impact of liquidity regulations on banks and the real economy.
\end{abstract}

Keywords: Bank Lending; Basel III; Liquidity Regulation; Liquidity Balance Rule; Liquidity Coverage Ratio; Propensity Score Matching.

JEL Classification: G21, G28

\footnotetext{
${ }^{1}$ Corresponding author. Tel: +33 555149251 .

Email addresses: foly.ananou@etu.unilim.fr (F.Ananou), amine.tarazi@unilim.fr (T.Amine), jsw7@st-andrews.ac.uk (J.O.S. Wilson)
} 


\title{
Liquidity Regulation and Bank Lending
}

This version: June 19, 2020

\begin{abstract}
Bank liquidity shortages during the global financial crisis of 2007-2009 led to the introduction of liquidity regulations, the impact of which has attracted the attention of academics and policymakers. In this paper, we investigate the impact of liquidity regulation on bank lending. As a setting, we use the Netherlands, where a Liquidity Balance Rule (LBR) was introduced in 2003. The LBR was imposed on Dutch banks only and did not apply to other banks operating elsewhere within the Eurozone. Using this differential regulatory treatment to overcome identification concerns and a difference-in-differences approach, we find that stricter liquidity requirements did not reduce the lending of Dutch banks relative to other banks not subject to the provisions of the LBR. However, the LBR did lead Dutch banks to modify the structure of loan portfolios by increasing corporate lending and reducing mortgage lending relative to banks not subject to the LBR. Dutch banks also experienced a significant increase in deposits and issued more equity relative to counterparts not subject to the liquidity requirements. Overall, our results have obvious relevance for policymakers tasked with monitoring the impact of liquidity regulations on banks and the real economy.
\end{abstract}

Keywords: Bank Lending; Basel III; Liquidity Regulation; Liquidity Balance Rule; Liquidity Coverage Ratio; Propensity Score Matching.

JEL Classification: G21, G28 


\section{Introduction}

This study investigates the impact of liquidity regulation on bank lending. During the global financial crisis of 2007-2009, regulators intervened extensively to provide short-term liquidity support to banks that were unable to meet short-term obligations. Since then, bank liquidity has attracted the attention of academics (Calomiris, Heider, and Hoerova 2015; De Nicolò 2016; Chiaramonte, 2018; Bouwman 2019) as policymakers have introduced rules requiring banks to hold more higher quality liquid assets. ${ }^{2}$ Proponents of these new regulations contend that by holding a greater proportion of liquid-to-total assets, banks are more resilient to sudden balance sheet shocks, and as a consequence can continue lending even during stressed periods (Schmaltz et al. 2014; Boissay and Collard 2016; Bressan 2018; Hoerova et al. 2018). However, opponents contend that regulatory compliance is costly, and could lead banks to reduce lending to households and firms with resulting negative consequences for the real economy (Cecchetti and Kashyap 2016; Birn, Dietsch, and Durant 2017). Given the paucity of evidence and ongoing empirical controversies, further research is required to assess the impact of liquidity regulation on bank lending behavior.

In this paper, we investigate how the introduction of a liquidity regulation in the Netherlands, known as the Liquidity Balance Rule (LBR) influences the lending activities of Dutch banks. Introduced in 2003, the LBR is similar in design to the Liquidity Coverage Ratio introduced by the Basel Committee on Banking Supervision following the global financial crisis. According to the LBR, banks are required to hold high-quality liquid assets

\footnotetext{
2 The Basel Committee on Banking Supervision introduced new capital and liquidity regulations embodied in Basel III, which were phased in between 2015 and 2019. Banks are not only required to hold more capital than before but must also comply with new liquidity standards. The liquidity standards framework specifies a liquidity coverage ratio (LCR) and a net stable funding ratio (NSFR). The LCR requires banks to operate with sufficient high-quality liquid assets to ensure survival of a stress scenario which lasts one month. The net stable funding ratio (NSFR) requires banks to operate with enough sufficient stable funding to ensure the continuance of operations over a one-year horizon.
} 
greater than or equal to net cash outflows over a 30-day stress period. In contrast to the more recently introduced Liquidity Coverage Ratio, the introduction of the LBR in the Netherlands did not occur following a period of financial instability, and so was unlikely to be anticipated in advance by banks and other industry stakeholders (such as shareholders, bondholders, and depositors). The LBR was imposed on Dutch banks only and did not apply to other banks operating elsewhere within the Eurozone or even within the other Benelux countries (Belgium and Luxembourg). Using this differential regulatory treatment to overcome identification concerns, we investigate the impact of liquidity regulation on the lending activities of banks.

Assessing the impact of liquidity regulation on bank lending presents a significant empirical challenge. Liquidity regulations are often part of a broader set of reforms that are anticipated in advance by industry stakeholders. Moreover, liquidity regulations (such as the Basel III Liquidity Coverage Ratio tend to be phased-in gradually over an extended period, during which time other significant events can take place. Consequently, isolating the impact of liquidity regulation from other significant events on bank lending is not an easy task. Our research design (discussed in detail in section 2), and subsequent empirical analysis (presented in section 3) allow us to tackle these issues and investigate the impact of liquidity regulation on bank lending using an unanticipated policy intervention in the Netherlands as a quasi-natural experiment.

In order to assess the impact of the LBR on bank lending, we adopt a difference-indifferences framework, where we estimate the difference in the behavior of the affected (Dutch) banks between the pre-LBR and post-LBR period with the same difference in the behavior of the unaffected group of banks (drawn from other Eurozone countries and, for robustness, only from fewer closer countries or even one single country such as Belgium, where the LBR did not apply). For this purpose, we follow previous literature based on 
European data (Roberts and Whited 2013; Schepens 2016) and use a group of matched banks drawn from European countries (where no LBR was introduced) as a control group. Our sample period straddles the introduction of the LBR, and comprises unconsolidated balance sheet, off-balance sheet and income statement data for commercial banks over the period 2000 to 2006 for 12 Eurozone member countries (Austria, Belgium, Finland, France, Germany, Greece, Ireland, Italy, Luxembourg, Netherlands, Portugal, and Spain). We complement our bank-level dataset with macroeconomic data collected from the Eurostat database. Dutch banks form the treated group. Banks located in other Eurozone countries are used to construct a control group that shares the characteristics of our treated group of Dutch banks prior to the introduction of the LBR. We use propensity score matching in order to avoid potential selection bias (Roberts and Whited 2013; Atanasov and Black, 2016). We also apply other restrictions for robustness considerations. In our baseline estimable model, we control for bank, industry and country characteristics.

The results of our empirical analysis indicate that the introduction of the LBR did not reduce the lending of Dutch banks relative to other banks located in the Eurozone that were not subject to the provisions of the LBR. On average, the volume of loans extended by affected banks was $15.9 \%$ higher than counterparts not subject to the provisions of the LBR. However, the loan portfolio structure of affected banks was impacted by the introduction of the LBR. On average, the stock of corporate and retail loans increased, while the volume of mortgage loans decreased (relative to unaffected banks). This suggests that the introduction of the LBR led Dutch banks to re-orientate asset portfolios toward more liquid assets. Our results also indicate that following the introduction of the LBR, affected banks made significant adjustments to other parts of their respective balance sheets, which led to an increase in size (relative to unaffected counterparts). More specifically, additional equity issuance and an inflow of retail deposits allowed Dutch banks to increase liquidity and 
maintain lending. Moreover, the introduction of the LBR appears to have improved overall confidence in the banking system, given that the inflow of additional retail deposits to Dutch banks occurred in the absence of changes in deposit rates.

In a series of additional tests, we assess the robustness of our main results. First, we: modify the number of selected banks; include additional bank-level covariates in the estimation of the propensity scores used to match treated and control banks; and restrict the pool of countries used to construct the control group of banks. Our main results are robust to these additional tests. Second, we perform a placebo test by falsely assuming that the LBR was introduced in an earlier time period. If banks anticipated the introduction of the LBR, we would expect to observe a change in bank lending during this period. The results of this placebo test do not indicate any anticipatory effects via changes in bank lending.

Our analysis contributes to the literature on bank liquidity in various ways. ${ }^{3}$ Prior evidence (using the Basel III Liquidity Coverage Ratio as a setting) suggests that the introduction of liquidity regulations leads banks to adjust asset structure rather than overall size (De Nicolò et al. 2014; Covas and Driscoll 2014; Bonner and Eijffinger 2016; De Nicolò, Gamba, and Lucchetta 2014), with a negative impact on lending (Hong, Huang, and Wu 2014; Chiaramonte and Casu 2017; Chiaramonte 2018; Reinhardt et al. 2020). Our study is most comparable to Banerjee and Mio (2018) who investigate the impact of the introduction of tighter liquidity regulations to the UK banking industry. The authors find that banks adjust the structure rather than size of balance sheets. Banks achieve this by increasing high-quality liquid assets, while reducing short-term inter-bank loans. Banks also reduce reliance on shortterm funding by increasing long-term liabilities. Contrary to these findings, our results suggest that in order to comply with the LBR, banks expand balance sheets by issuing equity

\footnotetext{
${ }^{3}$ Chiaramonte (2018) provides an extensive introduction and overview of recent literature on bank liquidity.
} 
and increasing deposits.

Our findings also lend support to the view that the impact of liquidity requirements on bank lending is crucially dependent on the availability of bank funding (Webb 2000; Bandt and Chahad 2016; Duijm and Wierts 2016). Prior evidence suggests that the potential negative impact of enhanced liquidity requirements is mitigated if banks can increase funding. Using a panel error correction approach, Duijm and Wierts (2016) examine how banks adjust balance sheets in order to comply with LBR requirements. They find that rather than increasing liquid assets, banks comply by relying more extensively on stable funding. Our results suggest that the increase in funding mitigates the reduction in lending that would otherwise be expected to take place following stricter liquidity requirements.

The remainder of the paper is structured as follows. Section 2 describes the institutional background to the Dutch Liquidity Balance Rule and presents the empirical methodology. In Section 3, we present the main results of our baseline estimable model along with the results of a series of additional tests carried out to ensure the validity of our main findings. Section 4 provides a brief summary.

\section{Background and Research Design}

\subsection{Identification}

To investigate the impact of liquidity regulation on bank lending, we rely on the introduction of the LBR in 2003. The LBR stipulates that banks should hold high-quality liquid assets greater than or equal to net cash outflows over a 30 -day stress period. ${ }^{4}$ The LBR is defined

\footnotetext{
4 The LBR is conceptually similar to the Basel III LCR ratio, which requires banks to hold a minimum level of liquid assets to meet a stress scenario of outflows. The main difference is in the weighting scheme and the range of items included in the stock of liquid assets (which is more extensive for the LBR compared to the LCR).
} 
as: $\mathrm{LBR}=\mathrm{AL} / \mathrm{RL} . \mathrm{AL}$ denotes Actual Liquidity and is defined as the sum of the stock of liquid assets and cash inflow scheduled within the next 30 days. RL denotes Required Liquidity and is defined as the sum of the stock of liquid liabilities and cash outflow scheduled within the next 30 days. The LBR ratio should be equal to or exceed one.

In order to account for market and funding liquidity risks, items included in AL and RL are weighted according to relative liquidity. ${ }^{5}$ During a period of stress, market illiquidity mean that only certain assets can be sold immediately (often at fire sale prices and resultant losses). In such a situation, the probability of withdrawal may differ depending on the nature of the liability. ${ }^{6}$

The time between the announcement and implementation of the LBR was relatively short, thus minimizing the possibility of anticipatory effects and subsequent changes in bank behavior prior to implementation. Announced in January 2003, banks had until July 2003 to comply with the terms of the LBR (de Haan and den End 2013). Every Dutch bank was subject to the rule. Branches of banks located in other countries of the European Union were exempt.

The LBR can be considered as a source of exogenous change in the proportion of liquid to total assets across banks. Given that the rule was introduced in January 2003, and implemented in July 2003, there was insufficient time for banks to make any major balance sheet adjustments in order to comply with the rule in advance of implementation. Extensive searches of regulatory reports and commentaries suggests that there were no information leaks

\footnotetext{
${ }^{5}$ The weight for each item is provided by the regulator (DNB 2011).

${ }^{6}$ For example, asset-backed securities are assigned a lower weight than high-quality bonds. Wholesale deposits are assigned a higher weight than retail deposits. Liquid assets (such as securities, inter-bank assets payable on demand and debts immediately due or payable by public authorities and professional money-market participants) are items that can be converted to cash quickly. Demand deposits held with non-credit institutions or nonprofessional money-market participants are not counted as part of the actual liquidity. Liquid liabilities comprise bank debt (such as deposits without a fixed maturity) that can be called upon immediately.
} 
that could have alerted banks to the pending announcement and provisions of the LBR. ${ }^{7}$ Therefore, it is unlikely that banks could have anticipated the LBR. Moreover, the period during which the LBR was announced and implemented was not marked by any significant regulatory or other change at the local or international level (IMF 2004). ${ }^{8}$

The LBR was unique to the Netherlands. Bank regulators based in other Eurozone countries did not consider this type of rule until the Global Financial Crisis of 2007-2009, when following international agreement, the Liquidity Coverage Ratio was introduced (Bonner and Hilbers 2015). Consequently, banks operating in Eurozone countries outside the Netherlands serve as a suitable sample from which a control group can be constructed.

\subsection{Data}

We collect financial statement items from the BankScope produced by Bureau van Dijk. This comprises unconsolidated balance sheet, off-balance sheet and income statement data of commercial banks from 2000 to 2006 for the Netherland and the 11 other European countries (Austria, Belgium, Finland, France, Germany, Greece, Ireland, Italy, Luxembourg, Portugal and Spain) forming the Eurozone in 2003 (the year of the introduction of the LBR). We restrict our sample to these countries for two reasons. First, to avoid changes in the composition of any possible control group arising from the accession of new countries to the Eurozone. Second, structural differences between countries should in theory be insignificant, and the banking system in each country would face the same constraints due to regulation We complement the bank-level data with macroeconomic data, retrieved from the Eurostat

\footnotetext{
${ }^{7}$ The introduction of a new rule often violates this exogeneity assumption because regulators communicate with industry stakeholders prior to announcement and implementation. If banks anticipate the introduction of a regulation, they may take pre-emptive action to comply or lessen any impacts prior to implementation. As a consequence, any change in bank behavior following actual implementation would be negligible.

${ }^{8}$ Dutch banks had relatively high levels of liquidity in the pre-treatment period (IMF 2004). Liquid assets had been high enough to cover 50\% of short-term liabilities since 1998.
} 
database. A full list of variables and accompanying definitions are provided in Table 1.

\section{[Insert Table 1 here]}

Our initial sample comprises 533 banks per year on average. We exclude 12 banks identified as branches of banks located in other Eurozone countries. This leaves us with a sample of 521 banks. To eliminate the undue influence of outliers, we winsorize all bankspecific variables at the 5th and 95th percentile. In order to reduce the possible impact of mergers and acquisitions that took place during the period, we also discard all bank-year observations where growth in total assets exceeds $25 \%$. To deal with reporting errors, we delete observations with negative assets and loans. Applying these filters, leaves around 90\% of the initial sample intact. The final sample comprises 458 banks per year on average. Table 2 provides further details on the number of banks by country.

\section{[Insert Table 2 here]}

\subsection{Model Specification}

To assess the impact of the LBR on bank lending, we use a difference-in-differences framework where we estimate the difference in the lending of affected banks between the preLBR and post-LBR period with the same difference in the behavior of the unaffected group of banks as follows:

$$
\mathrm{Y}_{i t}=\alpha_{i}+\beta_{0} \cdot \mathrm{T}_{t} \times \mathrm{C}_{i}+\beta_{1} \cdot \mathrm{DB}_{i} \times \mathrm{LBR}_{t}+\beta_{2} \cdot \mathrm{X}_{i, t-1}+\beta_{3} \cdot \mathrm{DB}_{i}+\beta_{4} \cdot \mathrm{LB}_{t}+e_{i t}
$$

where Y refers to bank lending, which is measured by lnLOAN, LOANFW and RATLOAN. lnLOAN is the log of total loans (stock of loans). LOANFW is the net flow of loans defined as the change in the stock of loans and unused commitments scaled by total assets and unused commitments as in Cornett et al. (2010). RATLOAN is total loans scaled by total assets. DB 
is a dummy variable equal to 1 for treated (Dutch) banks, and 0 for banks (located in other Eurozone countries) in the control group. LB is a dummy variable equal to 1 after 2003, and 0 otherwise.

$\mathrm{X}$ represents a set of control variables that prior literature considers as important determinants of bank lending. Bank size (SIZE) is measured as the natural logarithm of total assets. The effect of bank size on lending is ambiguous. Large banks may assume more risk than smaller counterparts, given expectations regarding the likelihood of official bailouts (in the event of failure). Moreover, large banks can also diversify asset portfolios, thus holding a lower stock of loans relative to total assets. Consequently, large banks are less likely to reduce loan portfolios in the event of a negative shock (Gambacorta et al. 2011; Jiménez et al. 2012; Popov and Van Horen 2015). In contrast, small banks are likely to specialize in traditional lending activities, and are thus more likely to curtail loans in event of a negative shock to liquidity (Petersen and Rajan 1994; Berger and Udell 1995). Loan quality is measured as the ratio of non-performing loans to gross loans (NPL). Prior evidence suggests that there is a significant negative correlation between NPL and lending (Chami et al., 2010; Stepanyan and Guo, 2011; Cucinelli, 2015). Funding is measured by the ratio of deposits to total assets (DEP). The importance of stable bank funding for credit supply was illustrated aptly during the global financial crisis of 2007-2009 when banks that were more reliant on traditional deposits maintained lending to households and firms (Cornett, McNutt, and Strahan, 2010; Chami et al., 2010). Consequently, when faced with stricter liquidity requirements, banks more dependent on deposits are more likely to continue lending relative to counterparts more reliant on wholesale funding. Regulatory capital (CAP) is measured by total risk-based capital ratio (Tier $1+$ Tier 2 / risk-weighted assets). Prior evidence suggests that there is a significant relationship between capital and lending (Berrospide and Edge 2010; Carlson, Shan, and Warusawitharana 2013; Kapan and Minoiu 2013). Given the ability to efficiently absorb 
negative shocks to loan portfolios, well capitalized banks are expected to extend more loans when faced with stricter liquidity requirements. Liquidity is measured by the ratio of liquidto-total assets (LIQ). LIQ is defined as the sum of trading securities, reserve repos, cash collateral, loans and advances to banks, cash and due from banks minus mandatory reserves. Prior evidence suggests that more liquid banks tend to lend more than counterparts holding higher proportions of illiquid assets (Cornett et al., 2010; Kim and Sohn, 2017). Hence, we expect a positive relationship between LIQ and lending.

Economic conditions and monetary policy are measured by the real GDP growth (GROWTH) and inflation (INFL) respectively. Given that economic conditions determine consumption and investment demand, (and thus reflect the demand for credit) higher GDP is likely to be translated into higher credit growth (Frankel and Romer 1999; Takats 2010). Inflation is likely to negatively impact lending, given that financial intermediaries are less willing to fund new projects in an inflationary environment (Bernanke and Blinder 1988).

In order to avoid simultaneity, we lag each of our control variables by one period. Our model also includes bank-specific fixed effects, $\alpha_{i}$, to control for unobserved bank level heterogeneity. $\beta_{1}$ is the coefficient of interest, representing the impact of the LBR on lending. We include country-year fixed effects to control for changes in domestic loan demand.

Table 3 presents the correlation matrix of all variables. The pairwise correlations suggest that the independent variables included in Equation 1 are not highly correlated. Consequently, multicollinearity issues are absent.

[Insert Table 3 here]

The identifying assumption for the difference-in-differences estimator is that in the absence of an intervention, bank lending of the treatment and control groups evolves in a 
similar fashion. This implies that changes in the lending of the control group are a valid counterfactual for the treatment group. Table 4 provides descriptive statistics for the main variables for the treatment (Dutch banks) and control groups (banks from other Eurozone countries) spanning the 2000-2006 period.

\section{[Insert Table 4 here]}

On average, banks operating in the Netherlands are more efficient and better capitalized than counterparts located in other Eurozone countries. Average loan-to-asset ratios are around $40 \%$ compared to a Eurozone average of $48 \%$. Net flows of loans represent $4.9 \%$ of total assets for Dutch banks, and $3.7 \%$ for banks located in other Eurozone countries. This suggests there are some structural differences across Eurozone banking systems. ${ }^{9}$ Therefore, the parallel trend assumption required to estimate a causal relation is likely to be violated. Fortunately, propensity score matching (PSM) can be used to construct a valid control group or to assign a weight to each bank in the control group; thus, ensuring comparability between the treatment and control group. In the present study, we follow Roberts and Whited (2013) and Schepens (2016), and use PSM to construct a suitable control group.

To construct the control group, we rely on the parallel trend assumption. According to this assumption, in the absence of treatment, the average outcome of the treatment group and the control group would evolve in parallel over time. In other words, the volume of loans in the pre-treatment period should follow the same trend for Dutch banks and banks in the control group. In order to construct an appropriate control group, we use propensity score matching where we select matches based upon trends in lending and other balance sheet characteristics in the pre-treatment period (prior to the introduction of the LBR). We use

\footnotetext{
${ }^{9}$ Goddard, Molyneux and Wilson (2010, 2015, 2019) provide detailed overviews of the banking systems of EU member states before, during and after the global financial crisis.
} 
nearest neighbor matching of propensity scores (Rosenbaum and Rubin, 1985). This involves estimating a logit regression for the full sample of banks in 2002, where the outcome variable DB (a dummy variable equal to 1 for treated banks, and 0 otherwise) is regressed on the contemporaneous growth rates of loans (LOANGW). To ensure that the control group and the treated group are balanced, and that any changes in loans are not due to other factors (Abadie 2003), we add as control variables to the logit model: bank size (measured by the natural logarithm of total assets); the growth rate of total deposits; the growth rate of total equity; the lagged value of loans; real GDP growth rate; and inflation. The predicted probabilities of the logit regression are used to match each Dutch bank with its three nearest neighbors. The matching is done with replacement. This means that each non-Dutch bank can serve as a control for multiple Dutch banks, thus improving the accuracy of the matching procedure (Smith and Todd, 2005).

\section{Results}

\subsection{Matching and Descriptive Analysis}

The matching procedure leads to a final sample of 83 banks, comprising 22 treated banks and 61 control banks. ${ }^{10}$ The impact of the matching is illustrated in Table 5, which presents summary statistics for the outcome variables of the treated and control banks. The growth of loans (LOANGW) is not significantly different across both groups in the pre-LBR period. This suggests that in the pre-treatment period, the evolution of loans for Dutch banks, and the matched banks forming the control group is not significantly different. Furthermore, we do not observe a significant difference between both groups on other bank characteristics.

\footnotetext{
10 The banks in the control group are headquartered in eight European countries: Austria (3), Belgium (14), France (10), Germany (12), Italy (11), Luxembourg (2), Portugal (2), and Spain (7).
} 
In the post-LBR period, Dutch banks experience a smaller decrease in loan growth as well as higher values in the overall stock of loans and in the ratio of loans to assets. The ratio of loans to total assets is on average $47 \%$ for Dutch banks, compared to $43 \%$ in the pre-LBR period, and the net flow of loans is $6.5 \%$ of total assets on average, compared to $6.1 \%$ in the pre-LBR period. Compared to the non-treated banks, we do not observe a significant difference for the ratio of loans to assets and for the overall stock of loans. However, the difference between Dutch banks and those included in the control group becomes significant for loan growth and loan flows. These figures do not represent any causal evidence regarding the impact of the LBR on lending, but rather tentative evidence that the introduction of the LBR changed the lending behavior of Dutch banks.

\section{[Insert Table 5 here]}

\subsection{Regression results}

Table 6 presents the results of estimating Equation 1. The outcome variables are: $\log$ of total loans, lnLoan (Panel A); the ratio of loan flows, LOANFW (Panel B); and the ratio of total loans to total assets, RATLOAN (Panel C). For each panel, we estimate two models over the 2000-2006 period. First, we regress our outcome variables on the covariates of interest only. We include country-year fixed effects to account for shocks to the economic environment at the country level, and bank fixed effects to account for any unobservable bank characteristics that might affect lending. Second, we add bank-specific control variables to capture any potential shocks in one of the time-varying determinants of bank lending as well as GDP growth and inflation, to capture the specific effect of the economic conditions and monetary policy. We also include country-year fixed effects and bank fixed effects.

[Insert Table 6 here] 
The $\beta_{1}$ coefficient on the interaction term, $D B_{i} \times L B R_{t}$, (which represents the average treatment effect of the LBR rule on loans) is positive and statistically significant when InLOAN and LOANFW are the outcome variables of interest. This indicates that the introduction of the LBR has a positive and significant impact on both the stock and flow of loans. Following the introduction of the LBR, the average stock of loans for Dutch banks was $15.9 \%$ higher relative to banks not subject to the provisions of the LBR. ${ }^{11}$ The flow of loans for Dutch banks was 2.5 percentage points higher relative to banks not subject to the LBR. In the estimations using RATLOAN as the outcome variable, $\beta_{1}$ is positive, but not statistically significant. This indicates that the introduction of the LBR does not affect the loans to total assets ratio. This is in line with prior evidence (Bonner, 2016; Banerjee and Mio, 2018).

We dis-aggregate total loans into mortgage, retail and corporate loans, and then reestimate Equation $1 .^{12}$ The results are presented in Table 7. The LBR has a positive and significant impact on retail and corporate loans. On average in the post-treatment period, the stock of retail and corporate loans of Dutch banks was on average $9.4 \%$ higher relatively to banks in the control group. The flows of retail and corporate loans were 1.2 and 2.7 percentage points higher for Dutch banks relative to banks in the control group. This suggests that following the introduction of the LBR, the importance of mortgage loans declined, while the importance of corporate loans increased.

\section{[Insert Table 7 here]}

\footnotetext{
11 For a dummy variable, we cannot directly interpret the coefficient of the variable on the outcome variable in percentage terms. Therefore, we follow the transformation discussed by Giles $(1982): \hat{\beta}=100$ $\times\left[\exp \left(\hat{\alpha}-0.5 V\left(\alpha^{\wedge}\right)\right)-1\right]$, where $\beta^{\wedge}$ is the percentage change in the outcome variable when the dummy takes the value of $1 . \alpha^{\wedge}$ is the estimated coefficient and, $V\left(\alpha^{\wedge}\right)$ represents its variance. In the remainder of the paper, we use the transformed coefficient to discuss the impact of the LBR.

${ }^{12}$ We use the average distribution presented in reports from the Central Bank of each country included in the control group to dis-aggregate the data on loans for each year of the sample.
} 
Overall, the results presented in this section indicate that following the introduction of the LBR, Dutch banks did not reduce lending relative to counterparts not subject to the LBR. The ratio of loans to total assets did not change while the stock of loans and loan flows increased significantly relative to unaffected banks. This implies that the introduction of the LBR led Dutch banks to re-orientate their asset portfolios toward liquid assets, with an insignificant impact on the share of loans in balance sheet totals. Such adjustments would necessitate Dutch banks increasing liquidity on their balance sheets. This could be achieved by equity and debt issuance as a means of funding investment in liquid assets (Webb 2000). We investigate these possibilities in the following section.

\subsection{The impact of LBR on the Balance Sheet}

In order to examine the evolution of various asset and liability categories following the introduction of the LBR, we estimate the following equation:

$$
\mathrm{Y}_{i t}=\alpha_{i}+\beta_{0} \cdot \mathrm{T}_{t} \times \mathrm{C}_{i}+\beta_{1} \cdot \mathrm{DB}_{i} \times \mathrm{LBR}_{t}+\beta_{2} \cdot \mathrm{DB}_{i}+\beta 3 \cdot \mathrm{LB}_{t}+e_{i t}
$$

The outcome variables (Y) are: the ratio of liquid assets to total assets (LIQ); the ratio of securities to total assets (SECU); the ratio of mandatory reserves to total assets (RES); the ratio of equity to total assets (EQUITY); the ratio of customers deposits to total assets (CUSTD); the ratio of deposits from banks to total assets (BANKD); and the natural logarithm of total assets (SIZE).

Table 8 presents the results of the estimation of Equation 2. On the asset side of the balance sheet, the LBR has a positive and significant impact on liquid assets and securities, but a negative and significant impact on mandatory reserves. In the post-treatment period, the ratio of liquid to total assets and securities to total assets are higher for affected banks relative to unaffected counterparts, while the ratio of mandatory reserves to total assets (RES) is lower 
relative to unaffected banks. On the liability side of the balance sheet, the LBR has a significant and positive effect on the ratio of customer deposits-to-total assets, and the ratio of bank deposits-to-total assets for Dutch banks. The ratio of customer deposits-to-total assets and the ratio of bank deposits-to total assets are higher for Dutch banks relative to counterparts not subject to the LBR. These findings are in line with prior research which suggests that that following the introduction of the LBR, deposits increased for Dutch banks (Duijm and Wierts, 2016)). Furthermore, it appears that following the introduction of the LBR, Dutch banks increased equity. The ratio of equity to total assets for the average Dutch bank is higher than the average bank in the control group. The results in the final column of Table 8 suggest that Dutch banks have grown faster than counterparts not subject to the LBR. The total assets for the average Dutch bank are higher than the total assets for the average bank in the control group.

\section{[Insert Table 8 here]}

In contrast to prior evidence (Banerjee and Mio 2018), our results suggest that the introduction of the LBR led Dutch banks to invest in securities as they experienced a growth in deposits and equity relative to counterparts not subject to the liquidity requirements. These adjustments led to an overall increase in the size of balance sheets. Taken together, these results suggest that following the introduction of the LBR, Dutch banks expanded liabilities relative to counterparts not subject to the liquidity requirements. This allowed them to invest in liquid assets without having to reduce the share of loans in overall asset portfolios.

\subsection{Sensitivity Tests}

In this section, we examine the robustness of our main results to: variations in the matching procedure; the inclusion of additional independent variables; restrictions on the 
geographic coverage of the control group; and the false timing of the introduction of the LBR.

First, we test whether variations in matching affect our baseline results. We vary the number of matched banks from three nearest neighbors to the nearest neighbor only, and then to the five nearest neighbors. Second, we add additional bank-specific variables to the matching procedure in order to test whether the matching procedure is biased due to omitted variables. We augment our baseline specification set of controls (comprising growth rates of loans, bank size, the growth rate of total deposits, the growth rate of total equity, the lagged value of the loan ratio, GDP growth rate and inflation) with non-interest income share (measured as the ratio of non-interest income to total assets), non-interest expense share (measured as the ratio of non-interest expense to total assets), and return on assets (measured as the ratio of net profits-to-total assets). Third, we restrict the number of countries from which banks in the control group are selected. We consider using Belgium and Luxembourg as the two BENELUX countries. ${ }^{13}$ However, given the specific nature of the banking system in Luxembourg (which is focused on wealth management), we consider Belgian banks only. ${ }^{14}$

The results are presented in Table 9. The coefficient of the interaction term is positive and statistically significant whether we consider one or five nearest neighbor matches in Panel $\mathrm{A}$ and $\mathrm{B}$, but not in Panel $\mathrm{C}$. The inclusion of additional variables in the matching procedure or restricting the countries in the sample does not affect the results. Moreover, the magnitude of the impact is comparable to that obtained in our baseline analysis. Regarding lnLOAN, we observe an average impact of around $15 \%$ in the different models. Regarding LOANFW, we obtain an average impact of around three percentage points.

\footnotetext{
13 The matching procedure leads to a final sample of 42 banks, of which 17 treated Dutch banks and 25 control group banks (4 from Luxembourg and 19 from Belgium).

14 The final sample after running the matching comprises 16 Dutch banks (treated group) and 18 Belgian banks (control group).
} 
Fourth, we perform a placebo test, where we assume falsely that the LBR was implemented in 2001 rather than 2003. As the rule was not introduced in 2002, the estimated treatment effect should not be statistically significant. We re-run the matching based on the full sample of 2001. The matching procedure is the same as that used in the baseline analysis with 1998-2000 as the pre-treatment period. The placebo test also yields the expected results. The coefficient of the interaction term is not statistically significant.

\section{[Insert Table 9 here]}

Finally, we test whether variations in matching affects the estimates derived for the different balance sheet items. Table 10 reports the results of the estimations. The main results still hold. The coefficient of the interaction term shows carries the expected sign and is significant.

[Insert Table 10 here]

\subsection{Did banks follow an active policy to attract deposits?}

The introduction of the LBR led Dutch banks to increase securities holdings, equity capital and deposits. This suggests that Dutch banks made significant balance sheet adjustments to their balance sheets. While the increase in securities investments and equity are the direct result of the deliberate actions of banks, the growth in deposits can occur either passively or as a result of a deliberate price or non-price strategy designed to increase market share. However, if the implementation of the LBR improved confidence, deposits may increase regardless of any deliberate actions on the part of Dutch banks.

To investigate whether Dutch banks have engaged actively in strategies to attract deposits, we examine the impact of the LBR on the deposit rates offered by banks. We assume 
that an increase in deposit rates would be indicative of an active strategy to attract deposits. ${ }^{15}$

To assess the impact of the LBR on deposit rates, we estimate the following equation:

$$
\mathrm{Y}_{i t}=\alpha_{i}+\beta_{0} \cdot \mathrm{T}_{t} \times \mathrm{C}_{i}+\beta_{1} \cdot \mathrm{DB}_{i} \times \mathrm{LBR}_{t}+\beta_{2} \cdot \mathrm{DB}_{i}+\beta_{3} \cdot \mathrm{LB}_{t}+e_{i t}
$$

The outcome variable, $\mathrm{Y}$, is the deposit rate measured as the ratio of interest expense on deposits to total deposits (INTDEP). The model is estimated over the 2000-2006 period. Table 11 reports the results.

\author{
[Insert Table 11 here]
}

The coefficient of the interaction term is positive, but not statistically significant. This indicates that the introduction of the LBR did not impact deposit rates offered by the average Dutch bank. Hence, Dutch banks have not engaged in active pricing strategies in order to attract deposits. The implementation of the LBR may have improved depositor confidence, which in turn contributed to a higher deposit growth. In turn, this has allowed Dutch banks to maintain a stable level of lending.

\title{
4. Conclusion
}

This paper investigates the impact of bank liquidity regulation on lending using, as a setting, the introduction of the so-called Liquidity Balance Rule (LBR) implemented in the Netherlands in 2003. Using a difference-in-differences approach and propensity score matching techniques (to form an appropriate control group of banks to act as a benchmark for

\footnotetext{
15 The fact that banks may actively engage in strategies to attract deposits does not exclude the potential incentive effect of the introduction of the LBR. However, we assume that the effect of the former would be stronger. Given that the design and implementation of the LBR rule was not discussed publicly prior to its introduction, we assume that bank customers do not have full access to information. Hence, we can expect that depositor behaviour does not change in the short term. Moreover, Bonner and Eijffinger (2016) indicate that Dutch banks that were below the required level of liquidity charged lower interest on interbank loans, but paid higher interest on unsecured interbank funding, compared to banks operating above the required level of liquidity. Hence, we expect banks to offer higher rate on deposits as a mean to raise funding.
} 
our treated banks), our results indicate that following the introduction of the LBR, Dutch banks did not reduce lending relative to unaffected banks. On average, the net flows of loans were 2.5 percentage points higher than what would have been observed in the absence of the LBR. This led to a significant increase in the total stock of loans for affected banks, relative to counterparts not subject to the regulation. The volume of loans has been $15 \%$ higher relative to counterparts not subject to the LBR. By loan category, Dutch banks modified the structure of their respective loan portfolios. Specifically, Dutch banks extended more loans to the corporate sector, while reducing mortgage loans, relative to unaffected banks. Corporate loans for Dutch banks on average increased by 2.45 percentage points relative to an average Eurozone bank not subject to the LBR. Mortgage loans declined by 1.27 percentage points relative to an average Eurozone bank not subject to the LBR. Dutch banks also made significant adjustments to the liability side of balance sheets by increasing equity. They also experienced a significant inflow of customer deposits, relative to an average Eurozone bank not subject to the LBR. Hence, they have been able them to maintain lending despite stricter liquidity requirements.

Overall, the results of this study suggest that the imposition of stricter liquidity requirements does not reduce bank lending. Moreover, these stricter regulations appear to have contributed to higher depositor confidence, resulting in overall deposit growth at Dutch banks relative to unaffected banks. Given the similarity between the Dutch LBR and the Basel III Liquidity Coverage Ratio, our results have obvious relevance for policymakers tasked with monitoring the impact of liquidity regulations on banks and the real economy. Specifically, the similarity between the LBR and the Basel III Liquidity Coverage Ratio suggests that the post-crisis liquidity regulations may not be detrimental for bank lending activities and the real economy as many commentators and bank lobbyists have argued. Taken together with prior evidence regarding the impact of liquidity requirements on bank behavior, our results suggest 
that banks can rely on diverse strategies to comply with the Basel III Liquidity Coverage Ratio. Banks can alternatively increase their liquidity ratio by altering the size of their balance sheet or by modifying the composition of assets and liabilities. Most importantly, our results suggest that a reduction in bank lending appears unlikely regardless of the strategy banks follow in order to comply with Basel III liquidity requirements. 


\section{References}

Abadie, Alberto. 2003. "Semiparametric Instrumental Variable Estimation of Treatment Response Models." Journal of Econometrics 113(2):231-63.

Ayadi, Rym, Sami Ben Naceur, Barbara Casu \& Barry Quinn. 2016. "Does Basel Compliance Matter for Bank Performance?" Journal of Financial Stability 23(September 2013):1532.

Atanasov, Vladimir A., \& Bernard S. Black. 2019. "The Trouble with Instruments: ReExamining Shock-Based IV Designs." Northwestern Public Law Research Paper Number 15.

Banerjee, Ryan N. \& Hitoshi Mio. 2018. "The Impact of Liquidity Regulation on Banks." Journal of Financial Intermediation 35:30-44.

Berger, Allen N. \& Gregory F. Udell. 1995. "Relationship Lending and Lines of Credit in Small Firm Finance." The Journal of Business 68(3):351.

Bernanke, Ben S. \& Alan S. Blinder. 1988. "Credit, Money, and Aggregate Demand." American Economic Review 78(2):435-39.

Berrospide, Jose M. \& Rochelle M. Edge. 2010. "The Effects of Bank Capital on Lending: What Do We Know, and What Does It Mean?" International Journal of Central Banking 6(4):5--54.

Birn, M., M. Dietsch \& D. Durant. 2017. "How to Reach All Basel Requirements at the Same Time?" Débats Économiques et Financiers $\mathrm{N}^{\circ} 28$.

Boissay, Frederic \& Fabrice Collard. 2016. "Macroeconomics of Bank Capital and Liquidity Regulations.” BIS Working Papers $\mathrm{N}^{\circ} 596$.

Bonner, Clemens. 2016. "Preferential Regulatory Treatment and Banks' Demand for Government Bonds." Journal of Money, Credit and Banking 48(6):1195-1221.

Bonner, Clemens \& Sylvester C. W. Eijffinger. 2016. "The Impact of Liquidity Regulation on Bank Intermediation." Review of Finance 20(5):1945-79.

Bonner, Clemens \& Paul Hilbers. 2015. "Global Liquidity Regulation - Why Did It Take so Long?” DNB Working Paper $\mathrm{N}^{\circ} 455$.

Bouwman, Christa H. S. 2019. "Creation and Regulation of Bank Liquidity." in The Oxford Handbook of Banking, edited by A. N. Berger, P. Molyneux, and J. O. S. Wilson.

Bressan, Silvia. 2018. "The Impact of Banks ' Liquidity Reserves on Lending.” Journal of Banking Regulation 19(4):337-45.

Calomiris, Charles W., Florian Heider \& Marie Hoerova. 2015. "A Theory of Bank Liquidity Requirements.” Columbia Business School Research Paper 14-39.

Carlson, Mark, Hui Shan \& Missaka Warusawitharana. 2013. "Capital Ratios and Bank Lending: A Matched Bank Approach.” Journal of Financial Intermediation 22(4):66387.

Cecchetti, Stephen G. \& Anil K. Kashyap. 2016. "What Binds? Interactions between Bank Capital and Liquidity Regulations." in The Changing Fortunes of Central Banking. Cambridge University Press.

Chami, Ralph, Raphael A. Espinoza, Adolfo Barajas \& Heiko Hesse. 2010. "Recent Credit 
Stagnation in the Mena Region; What to Expect? What Can Be Done?" IMF Working Papers $\mathrm{N}^{\circ} 10 / 219$.

Chiaramonte, Laura. 2018. Bank Liquidity and the Global Financial Crisis. Palgrave MacMillan.

Chiaramonte, Laura \& Barbara Casu. 2017. "Capital and Liquidity Ratios and Financial Distress. Evidence from the European Banking Industry." The British Accounting Review 49(2):138-61.

Cornett, Marcia Millon, Jamie John McNutt \& Philip E. Strahan. 2010. "Liquidity Risk Management And Credit Supply in the Financial Crisis." Journal of Financial Economics 101(2):297-312.

Cucinelli, Doriana. 2015. "The Impact of Non-Performing Loans on Bank Lending Behavior: Evidence from the Italian Banking Sector.” Eurasian Journal of Business and Economics 8(16):59-71.

DNB. 2011. Regulating Liquidity under Wft. Amsterdam.

Duijm, Patty \& Peter Wierts. 2016. "The Effects of Liquidity Liabilities Regulation on Bank Assets And.” International Journal of Central Banking 12(2):385-411.

Frankel, Jeffrey A. \& David Romer. 1999. "Does Trade Cause Growth?” American Economic Review 89(3):379-99.

Gambacorta, Leonardo, David Marques-Ibanez, Leonardo Gambacorta \& David Marques-Ibanez. 2011. "The Bank Lending Channel: Lessons from the Crisis." Economic Policy 26(66):135-82.

Giles, David E. A. 1982. "The Interpretation of Dummy Variables in Semilogarithmic Equations: Unbiased Estimation.” Economics Letters 10(1-2):77-79.

de Haan, Leo \& Jan Willem van den End. 2013. "Bank Liquidity, the Maturity Ladder, and Regulation.” DNB Working Paper 276(50):289-95.

Hoerova, Marie, Caterina Mendicino, Kalin Nikolov, Glenn Schepens \& Skander Van den Heuvel. 2018. "Benefits and Costs of Liquidity Regulation." ECB Working Paper Series 2169.

Hong, Han, Jing-Zhi Huang \& Deming Wu. 2014. "The Information Content of Basel III Liquidity Risk Measures.” Journal of Financial Stability 15:91-111.

IMF. 2004. The Kingdom of the Netherlands: Netherlands: Financial System Stability Assessment, Including Reports on the Observance of Standards and Codes on the Following Topics: Banking Supervision, Securities Regulation, Insurance Regulation, and Payment Systems. International Monetary Fund.

Jiménez, Gabriel, Steven Ongena, José-Luis Peydró \& Jesús Saurina. 2012. "Credit Supply and Monetary Policy: Identifying the Bank Balance-Sheet Channel with Loan Applications." American Economic Review 102(5):2301-26.

Kapan, Tümer \& Camelia Minoiu. 2013. "Balance Sheet Strength and Bank Lending During the Global Financial Crisis." IMF Working Paper $\mathrm{N}^{\circ}$ 13/102.

Kim, Dohan \& Wook Sohn. 2017. "The Effect of Bank Capital on Lending: Does Liquidity Matter?" Journal of Banking and Finance 77:95-107.

De Nicolò, Gianni. 2016. "Liquidity Regulation: Rationales, Benefits and Costs." National Institute Economic Review 235(1):18-26. 
De Nicolò, Gianni, Andrea Gamba \& Marcella Lucchetta. 2014. "Microprudential Regulation in a Dynamic Model of Banking." Review of Financial Studies 27(7):2097-2138.

Petersen, Mitchell A. \& Raghuram G. Rajan. 1994. "The Benefits of Lending Relationships: Evidence from Small Business Data." The Journal of Finance 49(1):3-37.

Popov, Alexander \& Neeltje Van Horen. 2015. "Exporting Sovereign Stress: Evidence from Syndicated Bank Lending during the Euro Area Sovereign Debt Crisis*." Review of Finance 19(5):1825-66.

Reinhardt, Dennis, Stephen Reynolds, Rhiannon Sowerbutts \& Carlos Van Hombeeck. 2020. "Quality Is Our Asset: The International Transmission of Liquidity Regulation." Bank of England Staff Working Papers 860.

Roberts, Michael R. \& Toni M. Whited. 2013. "Endogeneity in Empirical Corporate Finance." Pp. 493-572 in Handbook of the Economics of Finance. Vol. 2, edited by George, Constantinides, H. Milton, and S. Rene. Elsevier.

Rosenbaum, Paul R. \&Donald B. Rubin. 1985. "Constructing a Control Group Using Multivariate Matched Sampling Methods That Incorporate the Propensity Score." American Statistician 39(1):33-38.

Schepens, Glenn. 2016. “Taxes and Bank Capital Structure.” Journal of Financial Economics 120(3):585-600.

Schmaltz, Christian, Sebastian Pokutta, Thomas Heidorn \& Silvio Andrae. 2014. "How to Make Regulators and Shareholders Happy under Basel III." Journal of Banking and Finance 46(1):311-25.

Smith, Jeffrey A. \& Petra E. Todd. 2005. "Does Matching Overcome LaLonde's Critique of Nonexperimental Estimators?" Journal of Econometrics 125(1-2):305-53.

Stepanyan, Vahram \& Kai Guo. 2011. "Determinants of Bank Credit in Emerging Market Economies.” IMF Working Paper $\mathrm{N}^{\circ} 11 / 51$.

Takats, Elod. 2010. "Was It Credit Supply? Cross-Border Bank Lending to Emerging Market Economies during the Financial Crisis.” BIS Quarterly Review 2:49--56.

Webb, David C. 2000. "The Impact of Liquidity Constraints on Bank Lending Policy." The Economic Journal 110(460):69-91. 
Table 1 - Definition of Variables

\begin{tabular}{|c|c|c|c|}
\hline Variable & Description & Unit & Source \\
\hline SIZE & Natural logarithm of total assets & $\%$ & Bankscope \\
\hline CAP & $\begin{array}{l}\text { Ratio of regulatory capital: Tier } 1+\text { Tier } 2 \text { capital which includes } \\
\text { subordinated debt, hybrid capital, loan loss reserves and the valuation } \\
\text { reserves as a percentage of risk weighted assets and off-balance sheet risks }\end{array}$ & $\%$ & Bankscope \\
\hline DEP & $\begin{array}{l}\text { Total deposits by customers, money market and short-term funding over total } \\
\text { assets of bank }\end{array}$ & $\%$ & Bankscope \\
\hline CUSTD & $\begin{array}{l}\text { Total deposits by customers, including current, saving and term accounts over } \\
\text { total assets }\end{array}$ & $\%$ & Bankscope \\
\hline BANKD & $\begin{array}{l}\text { Total deposits by banks, including deposits, loans and repos from banks overt } \\
\text { total assets }\end{array}$ & $\%$ & Bankscope \\
\hline LOANS & Outstanding loans on bank's balance sheet & $\begin{array}{l}\text { Millions } \\
\text { of euros }\end{array}$ & Bankscope \\
\hline COMMIT & Total of any undrawn credit facilities made available by the bank & $\begin{array}{l}\text { Millions } \\
\text { of euros }\end{array}$ & Bankscope \\
\hline NPL & $\begin{array}{l}\text { Ratio of total of non-performing loans to customers and other banks, over } \\
\text { gross loans }\end{array}$ & $\%$ & Bankscope \\
\hline LIQ & $\begin{array}{l}\text { Sum of trading securities, reserve repos, cash collateral, loans and advances } \\
\text { to banks, cash and due from banks minus mandatory reserves, over total } \\
\text { assets of bank }\end{array}$ & $\%$ & Bankscope \\
\hline SECU & $\begin{array}{l}\text { Ratio of the sum of reverse repos, cash collateral, trading securities, } \\
\text { derivatives, available for sale securities, held to maturity securities, at-equity } \\
\text { investments and other securities over total assets }\end{array}$ & $\%$ & Bankscope \\
\hline EQUITY & Ratio of total equity to total assets & $\%$ & Bankscope \\
\hline RES & Balances kept with the central bank as reserves, over total assets & $\%$ & Bankscope \\
\hline MORT & Ratio of mortgage loans to total assets & $\%$ & $\begin{array}{l}\text { Central bank } \\
\text { report and } \\
\text { Bankscope }\end{array}$ \\
\hline RETL & Ratio of retail loans to total assets & $\%$ & $\begin{array}{l}\text { Central bank } \\
\text { report and } \\
\text { Bankscope }\end{array}$ \\
\hline CORP & Ratio of corporate loans to total assets & $\%$ & $\begin{array}{l}\text { Central bank } \\
\text { report and } \\
\text { Bankscope }\end{array}$ \\
\hline NETINC & ratio of non-interest income over total assets & $\%$ & Bankscope \\
\hline NETEXP & ratio of non-interest expense over total assets & $\%$ & Bankscope \\
\hline ROA & Ratio of net profit over total assets & $\%$ & Bankscope \\
\hline GROWTH & Year-to-year growth rate of real GDP & $\%$ & Eurostat \\
\hline INFL & Year-to-year growth rate of harmonized price index & $\%$ & Eurostat \\
\hline LOANGW & $\begin{array}{l}\text { Year-to-year growth rate of the outstanding stock of loans on bank's balance } \\
\text { sheet }\end{array}$ & $\%$ & Computed \\
\hline LOANFW & $\begin{array}{l}\text { Ratio of the year-to-year difference of the sum of net granted loans and loan } \\
\text { commitments normalized by the sum of total assets and commitments at the } \\
\text { beginning of the period }\end{array}$ & $\%$ & Computed \\
\hline RATLOAN & Ratio of outstanding loans to total assets & $\%$ & Computed \\
\hline $\operatorname{lnLOAN}$ & Natural logarithm of total loans & $\%$ & Computed \\
\hline IMPLICIT & Ratio of interest expense over total deposits & $\%$ & Computed \\
\hline
\end{tabular}

This table presents definitions for all variables used throughout the paper. The first column shows the name of the variable as used throughout the paper, the second describes the corresponding definition and the third column gives the source. 
Table 2 - Distribution of Banks in the Sample by Country

\begin{tabular}{|c|c|c|c|c|c|c|c|c|c|c|c|c|}
\hline Country & Austria & Belgium & Finland & France & Germany & Greece & Ireland & Italy & Luxembourg & Netherlands & Portugal & Spain \\
\hline $\begin{array}{l}\text { Number } \\
\text { of banks }\end{array}$ & 38 & 24 & 8 & 81 & 79 & 12 & 12 & 81 & 52 & 28 & 12 & 31 \\
\hline
\end{tabular}

This table indicates for each country, the number of banks included in the sample.

Table 3 - Correlation Matrix

\begin{tabular}{|c|c|c|c|c|c|c|c|c|c|c|c|}
\hline & 1. & 2. & 3. & 4. & 5. & 6. & 7. & 8. & 9. & 10. & 11. \\
\hline 1. $\operatorname{lnLOAN}$ (Log of total stock of loans) & 1.00 & & & & & & & & & & \\
\hline 2. LOANFW (Loans' flows) & 0.12 & 1.00 & & & & & & & & & \\
\hline 3. RATLOAN (Loans ratio) & 0.17 & 0.27 & 1.00 & & & & & & & & \\
\hline 4. SIZE (Natural logarithm of total assets) & -0.19 & 0.03 & -0.19 & 1.00 & & & & & & & \\
\hline 5. CAP (Total Reg. Capital Ratio) & -0.15 & 0.04 & -0.15 & -0.07 & 1.00 & & & & & & \\
\hline 6. DEP (Deposits share) & 0.03 & -0.18 & 0.04 & -0.15 & -0.13 & 1.00 & & & & & \\
\hline 7. NPL (Non-performing loans) & -0.09 & -0.19 & -0.08 & -0.08 & -0.02 & 0.09 & 1.00 & & & & \\
\hline 8. EQUITY (Equity ratio) & -0.14 & 0.07 & -0.16 & -0.09 & 0.19 & -0.44 & -0.01 & 1.00 & & & \\
\hline 9 GROWTH (Real GDP growth rate) & -0.24 & -0.21 & -0.24 & 0.06 & -0.02 & 0.33 & 0.15 & -0.15 & 1.00 & & \\
\hline 10. INFL (Inflation) & -0.06 & -0.30 & -0.06 & -0.13 & -0.11 & 0.27 & 0.29 & -0.18 & 0.20 & 1.00 & \\
\hline 11. LIQ (Liquid Assets ratio) & -0.63 & -0.03 & -0.63 & 0.14 & 0.17 & -0.10 & 0.00 & 0.02 & 0.02 & -0.08 & 1.00 \\
\hline
\end{tabular}

This table reports the correlation matrix for the outcome variables and control variables used in our analysis. 


\begin{tabular}{lccccccccccc}
\hline & \multicolumn{4}{c}{ Dutch banks } & \multicolumn{4}{c}{ Other Eurozone banks } \\
\cline { 2 - 12 } & obs. & mean & $\begin{array}{c}\text { Std. } \\
\text { dev. }\end{array}$ & min & max & obs. & mean & $\begin{array}{c}\text { Std. } \\
\text { dev. }\end{array}$ & min & $\max$ \\
\hline RATLOAN (Loans ratio) & 116 & 40.2 & 7.9 & 34.4 & 63.5 & 1893 & 48.4 & 9.0 & 31.0 & 78.5 \\
LOANGW (Loans growth rate) & 116 & 0.11 & 0.1 & -2.1 & 0.7 & 1893 & -0.07 & 1.1 & -2.4 & 1.7 \\
LOANFW (Loans' flows) & 116 & 4.9 & 3.6 & -4.7 & 8.5 & 1893 & 3.7 & 4.2 & -2.3 & 13.2 \\
lnLOAN (Log of total stock of loans) & 116 & 13.88 & 1.6 & 11.7 & 16.2 & 1893 & 13.46 & 1.2 & 12.1 & 15.4 \\
SIZE (Natural logarithm of total assets) & 116 & 15.2 & 1.8 & 13.1 & 17.5 & 1893 & 14.1 & 1.4 & 12.7 & 16.0 \\
CAP (Total Reg. Capital Ratio) & 116 & 17.5 & 7.5 & 10.1 & 27.5 & 1893 & 14.1 & 6.1 & 9.4 & 20.9 \\
DEP (Deposits share) & 116 & 59.2 & 12.1 & 54.4 & 78.7 & 1893 & 65.2 & 6.4 & 55.9 & 72.6 \\
NPL (Non-performing loans) & 116 & 3.7 & 1.9 & 2.9 & 6.8 & 1893 & 6.2 & 3.8 & $0 ; 8$ & 11.9 \\
EQUITY (Equity ratio) & 116 & 5.6 & 8.5 & 2.3 & 13.8 & 1893 & 8.4 & 7.2 & 3.6 & 11.8 \\
GROWTH (Real GDP growth rate) & 116 & 1.4 & 0.2 & -3.7 & 4.2 & 1893 & 1.6 & 1.2 & -8.7 & 10.6 \\
INFL (Inflation) & 116 & 0.3 & 0.2 & 0.3 & 2.6 & 1893 & 0.7 & 0.4 & -1.4 & 5.4 \\
LIQ (Liquid Assets ratio) & 116 & 23.4 & 5.2 & 2.7 & 54.9 & 1893 & 18.1 & 4.6 & 5.0 & 40.2 \\
\hline
\end{tabular}

This table reports summary statistics of the outcome variables and the control variables for Dutch banks and non-Dutch banks for the full sample over the period 2000-2006.

Table 5 - Summary Statistics of Outcome and Control Variables for Treatment and Control Group

\begin{tabular}{lcccccc}
\hline & \multicolumn{3}{c}{ Before LBR } & \multicolumn{3}{c}{ After LBR } \\
\cline { 2 - 7 } & Treated & $\begin{array}{c}\text { non- } \\
\text { Treated }\end{array}$ & p-value & Treated & $\begin{array}{c}\text { non- } \\
\text { Treated }\end{array}$ & p-value \\
\hline RATLOAN (Loans ratio) & 43.91 & 42.37 & 0.41 & 47.42 & 46.84 & 0.92 \\
lnLOAN (Log of total stock of loans) & 13.73 & 13.91 & 0.42 & 14.12 & 12.81 & 0.16 \\
LOANFW (Loans' flows) & 6.11 & 5.72 & 0.37 & 6.49 & 4.94 & 0.09 \\
LOANGW (Loans growth rate) & -0.10 & -0.08 & 0.99 & -0.07 & -0.15 & 0.01 \\
SIZE (Natural logarithm of total assets) & 14.81 & 15.04 & 0.15 & 15.15 & 14.17 & 0.40 \\
CAP (Total Reg. Capital Ratio) & 17.20 & 16.71 & 0.98 & $15 . .25$ & 16.71 & 0.38 \\
DEP (Deposits share) & 32.53 & 31.98 & 0.74 & 35.36 & 30.09 & 0.00 \\
NPL (Non-performing loans ratio) & 3.58 & 5.91 & 1.00 & 3.79 & 6.22 & 1.00 \\
EQUITY (Equity ratio) & 5.23 & 5.57 & 0.99 & 6.23 & 7.2 & 1.00 \\
LIQ (Liquid Assets ratio) & 24.86 & 22.38 & 0.70 & 25.95 & 20.38 & 0.99 \\
\hline
\end{tabular}

This table compares banks characteristics of the treated (Dutch) banks to the non-treated banks after the matching. The table reports the mean and the p-value of the mean comparison test of the treatment group, the control group obtained via the matching in the pre-treatment (2000-2002) and in the post-treatment period (2003-2006). In the first three columns, we compare Dutch banks with the control group constructed via the matching, in the pre-LBR period. The last part of the table presents the statistics for Dutch banks and reports the p-value of the results of the mean comparison test of the control group in the post-LBR period. The null hypothesis of the mean comparison test is that the difference of mean is equal to zero. The alternative hypothesis is that that difference is greater than zero. The rejection of the null hypothesis, corresponding to a p-value inferior to $5 \%$, implies that the mean of the variable is significantly higher for the group of non-Dutch in comparison to Dutch banks. If it's not rejected and 1-p is inferior to 5\% then the mean of the variable is significantly greater for Dutch banks in comparison to non-Dutch banks. 
Table 6 - Regression Results: Baseline Model

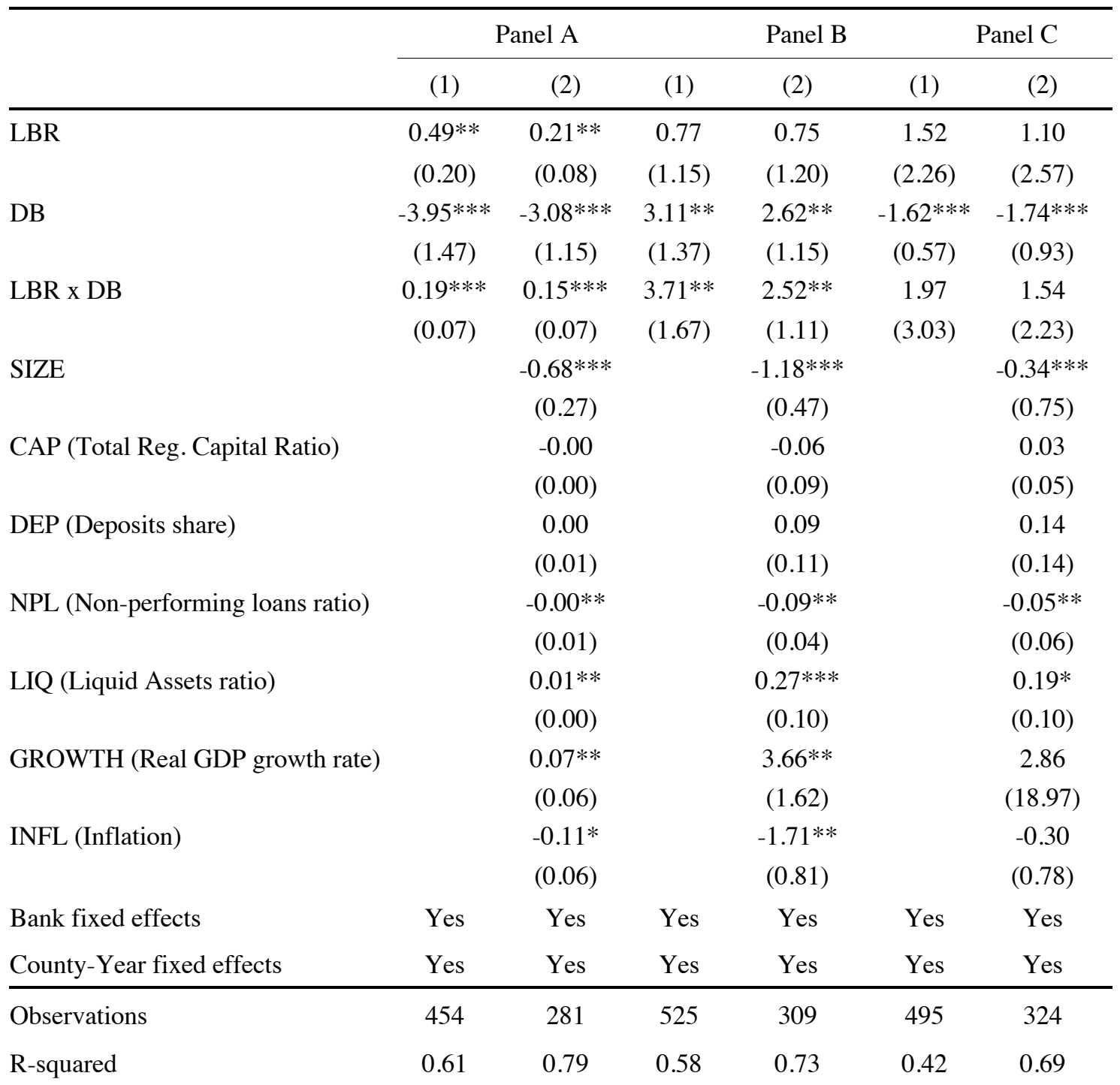

The table analyses the impact of the introduction of the Liquidity Balance Rule in the Netherlands in a difference-in-differences setup. The sample consists of banks from the Netherlands and the matched non-Dutch banks over the 2000-2006 period. The outcome variable is either the log of total loan volume (Panel A), or the year-to-year variation of the sum of total loans and unused commitments over the lagged sum of total assets and unused commitments (Panel B) or the ratio of total loans to total assets (Panel C). For each panel, the first column shows the regression of the outcome variable on a post-event dummy that equal to one in 2003-3006 (LBR), a dummy indicating if the bank is a Dutch bank (DB), and an interaction term between both dummies that captures the impact of the introduction of the LBR. The second column for each panel, control variables are added. The control variables comprise SIZE defined as the natural logarithm of total assets, NPL defined as the ratio of non-performing loans to gross loans. DEP is defined as the ratio of deposits to total assets. CAP is defined as the total risk-based capital ratio (Tier $1+$ Tier 2/ risk-weighted assets), and LIQ is ratio of liquid to total assets (LIQ). GROWTH is the real GDP growth rate and INFLATION is the growth rate of the harmonized price index. For Panel A, the outcome variable is in log; therefore, we cannot directly interpret the coefficient of the dummy on the outcome variable in percentage terms, as for a continuous variable. The appropriation transformation to get similar interpretation, is given by Giles $(1982): \beta^{\wedge}=100 \times\left[\exp \left(\alpha^{\wedge}-0.5 \mathrm{~V}\left(\alpha^{\wedge}\right)\right)-1\right]$, where $\beta^{\wedge}$ is the percentage change in the outcome variable when the dummy takes the value of $1 . \alpha^{\wedge}$ is the estimated coefficient and, $\mathrm{V}\left(\alpha^{\wedge}\right)$ represents its variance. The effect of the LBR is captured by the coefficient of "LBRxDB". Standard errors are clustered at the bank level. *, **, *** indicate significance at the $10 \%, 5 \%$, and $1 \%$ levels, respectively. 
Table 7 - Regression Results: Type of Loans

\begin{tabular}{lccccccccc}
\hline & \multicolumn{3}{c}{ Panel A } & \multicolumn{3}{c}{ Panel B } & \multicolumn{3}{c}{ Panel C } \\
\cline { 2 - 10 } & MORT & RETL & CORP & MORT & RETL & CORP & MORT & RETL & CORP \\
\hline LBR & $0.13^{* * *}$ & $0.13^{* * *}$ & $0.13^{* * *}$ & 0.14 & 0.05 & 0.66 & 0.28 & 0.44 & 0.35 \\
DB & $(0.04)$ & $(0.04)$ & $(0.04)$ & $(0.20)$ & $(0.07)$ & $(0.52)$ & $(0.41)$ & $(0.65)$ & $(0.52)$ \\
& $-2.63^{* * *}$ & $-1.28^{* * *}$ & -0.30 & $-3.60^{* *}$ & $3.98^{* * *}$ & $-5.18^{* * *}$ & $-1.18^{* * *}$ & -1.82 & $1.49^{* *}$ \\
LBR x DB & $(0.98)$ & $(0.47)$ & $(0.47)$ & $(1.78)$ & $(1.92)$ & $(1.98)$ & $(0.59)$ & $(2.81)$ & $(0.55)$ \\
& 0.011 & $0.09^{* *}$ & $0.09^{* *}$ & 1.27 & $1.16^{* * *}$ & $2.74^{* * *}$ & $-1.27 * * *$ & 0.61 & $2.45^{* * *}$ \\
Controls & $(0.44)$ & $(0.03)$ & $(0.03)$ & $(1.92)$ & $(0.49)$ & $(1.02)$ & $(0.56)$ & $(0.88)$ & $(0.93)$ \\
Bank fixed effects & Yes & Yes & Yes & Yes & Yes & Yes & Yes & Yes & Yes \\
County-Year FE & Yes & Yes & Yes & Yes & Yes & Yes & Yes & Yes & Yes \\
\hline Observations & 248 & 248 & 248 & 248 & 248 & 248 & 248 & 248 & 248 \\
R-squared & 0.79 & 0.79 & 0.69 & 0.64 & 0.68 & 0.54 & 0.69 & 0.78 & 0.89 \\
\hline
\end{tabular}

The table analyses the impact of the introduction of the Liquidity Balance Rule on the main components of loans portfolio (mortgage, retail and corporate). The sample consists of banks from the Netherlands and the matched non-Dutch banks over the 2000-2006 period. The outcome variable is either the log of total loan volume (Panel A), or the year-to-year variation of the sum of total loans and unused commitments over the lagged sum of total assets and unused commitments (Panel B) or the ratio of total loans to total assets (Panel C), for each type of loans. The set of controls includes: SIZE, defined as the natural logarithm of total assets; NPL, measured as the ratio of non-performing loans to gross loans; DEP, defined as the ratio of deposits to total assets; CAP, defined as the total risk-based capital ratio (Tier $1+$ Tier 2/ risk-weighted assets), and LIQ measured as the ratio of liquid to total assets (LIQ). The effect of the LBR is captured by the coefficient of "LBRxDB". Standard errors are clustered at the bank level. *,**,*** indicate significance at the $10 \%, 5 \%$, and $1 \%$ levels, respectively.

Table 8 - Regression Results: Impact of LBR on Bank Balance Sheets

\begin{tabular}{lccccccc}
\hline & LIQ & RES & SECU & EQUITY & CUSTD & BANKD & SIZE \\
\hline LBR & -2.31 & 0.14 & 3.21 & $-0.59^{* *}$ & -1.63 & 0.17 & $0.25^{* * *}$ \\
& $(2.88)$ & $(0.17)$ & $(4.73)$ & $(0.26)$ & $(2.39)$ & $(0.25)$ & $(0.09)$ \\
DB & -4.03 & -0.05 & $6.28^{* *}$ & $-1.90^{* *}$ & $2.10^{* * *}$ & $-3.16^{* * *}$ & $0.86^{*}$ \\
& $(6.03)$ & $(0.08)$ & $(2.81)$ & $(0.81)$ & $(0.78)$ & $(1.85)$ & $(0.68)$ \\
LBR x DB & $0.05^{* *}$ & $-0.11^{* *}$ & $0.18^{* *}$ & $1.29^{* *}$ & $0.78^{* *}$ & $1.17^{* *}$ & $0.07^{* *}$ \\
& $(0.02)$ & $(0.05)$ & $(0.07)$ & $(079)$ & $(0.34)$ & $(0.81)$ & $(0.02)$ \\
Bank fixed effects & Yes & Yes & Yes & Yes & Yes & Yes & Yes \\
Country-Year fixed effects & Yes & Yes & Yes & Yes & Yes & Yes & Yes \\
\hline Observations & 528 & 427 & 518 & 525 & 500 & 480 & 528 \\
R-squared & 0.73 & 0.75 & 076 & 0.72 & 0.75 & 0.78 & 0.65 \\
\hline
\end{tabular}

This table analyses the impact of LBR on the balance sheet items, except for loans. Columns 1 to 3 reports results for the assets side, while columns 4 to 6 reports the results for the liabilities side and the last columns presents the results for the size. The sample consists of banks from The Netherlands and the matched non-Dutch banks over the period 2000 2006. The effect of the LBR is captured by the coefficient of "LBRxDB". All the left-hand side variables are expressed in percentage, except for SIZE. SIZE is in natural logarithm. For this variable, we cannot directly interpret the coefficient of the dummy on the outcome variable in percentage terms, as for a continuous variable. The appropriation transformation to get similar interpretation, is given by Giles (1982): $\beta^{\wedge}=100 \times\left[\exp \left(\alpha^{\wedge}-0.5 \mathrm{~V}\left(\alpha^{\wedge}\right)\right)-1\right]$, where $\beta^{\wedge}$ is the percentage change in the outcome variable when the dummy takes the value of $1 . \alpha^{\wedge}$ is the estimated coefficient and, $\mathrm{V}\left(\alpha^{\wedge}\right)$ represents its variance. Standard errors are clustered at the bank level. *,**,*** indicate significance at the $10 \%, 5 \%$, and $1 \%$ levels, respectively. 
Table 9 - Impact of LBR on bank lending: Sensitivity Tests

\begin{tabular}{|c|c|c|c|c|c|c|}
\hline & $\begin{array}{c}\text { One } \\
\text { Neighbor }\end{array}$ & $\begin{array}{c}\text { Five } \\
\text { Neighbors }\end{array}$ & $\begin{array}{l}\text { Matching } \\
\text { variables }\end{array}$ & $\begin{array}{l}\text { Control } \\
\text { countries }\end{array}$ & $\begin{array}{l}\text { Belgium } \\
\text { only }\end{array}$ & Placebo \\
\hline \multicolumn{7}{|c|}{ Panel A : $\log$ of total loans (lnLOAN) } \\
\hline \multirow[t]{2}{*}{ LB } & $0.04 * *$ & $0.32 * *$ & $0.23 * *$ & 0.20 & 0.21 & 0.19 \\
\hline & $(0.02)$ & $(0.14)$ & $(0.43)$ & $(0.31)$ & $(0.31)$ & $(0.28)$ \\
\hline \multirow[t]{2}{*}{ DB } & 0.19 & 0.23 & $-4.53 * * *$ & -0.84 & -0.85 & -0.30 \\
\hline & $(0.30)$ & $(0.40)$ & $(1.81)$ & $(1.33)$ & $(1.41)$ & $(0.44)$ \\
\hline \multirow[t]{2}{*}{ LB $x$ DB } & $0.16^{* *}$ & $0.17 * *$ & $0.17 * *$ & $0.11 * *$ & $0.11 * *$ & -0.13 \\
\hline & $(0.09)$ & $(0.08)$ & $(0.07)$ & $(0.07)$ & $(0.07)$ & $(0.20)$ \\
\hline Controls & Yes & Yes & Yes & Yes & Yes & Yes \\
\hline Bank fixed effects & Yes & Yes & Yes & Yes & Yes & Yes \\
\hline County-Year fixed effects & Yes & Yes & Yes & Yes & Yes & Yes \\
\hline Observations & 134 & 418 & 309 & 147 & 83 & 309 \\
\hline R-squared & 0.69 & 0.75 & 0.79 & 0.77 & 0.87 & 0.67 \\
\hline \multicolumn{7}{|c|}{ Panel B : loan flow (LOANFW) } \\
\hline \multirow[t]{2}{*}{$\overline{\mathrm{LB}}$} & 1.04 & 1.30 & 1.31 & 0.57 & 0.24 & 1.58 \\
\hline & $(1.49)$ & (1.99) & (1.99) & $(0.84)$ & $(0.41)$ & $(2.41)$ \\
\hline \multirow[t]{2}{*}{ DB } & $1.31 * *$ & $1.48 * *$ & $3.48 * *$ & $2.77 * *$ & $3.14 * *$ & $3.09 * * *$ \\
\hline & $(0.59)$ & $(0.65)$ & (1.54) & $(1.36)$ & $(1.46)$ & $(1.17)$ \\
\hline \multirow[t]{2}{*}{ LB x DB } & $2.53 * *$ & $3.18 * *$ & $3.27 * *$ & $2.73 * *$ & $2.71 * *$ & -1.36 \\
\hline & $(1.11)$ & $(1.51)$ & $(1.51)$ & $(1.37)$ & $(1.28)$ & $(2.20)$ \\
\hline Controls & Yes & Yes & Yes & Yes & Yes & Yes \\
\hline Bank fixed effects & Yes & Yes & Yes & Yes & Yes & Yes \\
\hline Country-Year fixed effects & Yes & Yes & Yes & Yes & Yes & Yes \\
\hline Observations & 134 & 418 & 309 & 147 & 83 & 309 \\
\hline R-squared & 0.73 & 0.78 & 0.83 & 0.69 & 0.69 & 0.81 \\
\hline \multicolumn{7}{|c|}{ Panel C : ratio of loans to total assets (RATLOAN) } \\
\hline \multirow[t]{2}{*}{$\overline{\mathrm{LBR}}$} & 1.53 & 1.23 & 1.67 & 1.20 & 1.05 & 1.68 \\
\hline & $(2.29)$ & (1.89) & $(2.34)$ & $(2.81)$ & (1.49) & $(2.47)$ \\
\hline \multirow[t]{2}{*}{ DB } & $-2.05 * *$ & $-2.05^{* *}$ & $-2.09 * *$ & $-1,56^{* *}$ & $-1.82 * *$ & $-1.70 * * *$ \\
\hline & (1.08) & $(0.98)$ & (1.17) & $(0.72)$ & $(0.81)$ & $(0.63)$ \\
\hline \multirow[t]{2}{*}{ LBR $x$ DB } & 1.39 & 1.41 & 1.77 & 1.29 & 1.32 & 1.67 \\
\hline & $(2.15)$ & $(2.15)$ & $(2.72)$ & $(1.86)$ & $(2.01)$ & $(2.51)$ \\
\hline Controls & Yes & Yes & Yes & Yes & Yes & Yes \\
\hline Bank fixed effects & Yes & Yes & Yes & Yes & Yes & Yes \\
\hline Country-Year fixed effects & Yes & Yes & Yes & Yes & Yes & Yes \\
\hline Observations & 134 & 418 & 309 & 147 & 83 & 309 \\
\hline R-squared & 0.62 & 0.64 & 0.74 & 0.63 & 0.81 & 0.56 \\
\hline
\end{tabular}

The table analyses the sensitivity of the baseline model to variations in the matching procedure and false timing of the introduction of the LBR (placebo). The first four columns address the matching procedure while the last column reports the results of a placebo test. Regarding the matching procedure, we consider respectively the closest neighbor as matched bank for each Dutch bank and the nearest five neighbors. Next, we add some bankspecific variables in the estimation of the propensity score and finally, we restrict the countries from which to select the banks to be included in the control group. Firstly, we consider Belgium and Luxembourg first as the form with the Netherlands the BENELUX and then, we restrict the sample to Belgium and the Netherlands, given the specific nature of banking in Luxembourg. Panel A presents the results using the natural logarithm of the stock of loans as outcome variable, Panel B reports the results using loans' flows as outcome variable for and 
Panel C reports the results for the ratio of total loans to total assets. The set of controls includes: SIZE, defined as the natural logarithm of total assets; NPL, measured as the ratio of non-performing loans to gross loans; DEP, defined as the ratio of deposits to total assets; CAP, defined as the total risk-based capital ratio (Tier $1+$ Tier $2 /$ risk-weighted assets), and LIQ measured as the ratio of liquid to total assets (LIQ). The effect of the LBR is captured by the coefficient of "LBRxDB". Standard errors are clustered at the bank level. *, **, *** indicate significance at the $10 \%, 5 \%$, and $1 \%$ levels, respectively.

Table 10 - Impact of LBR on Bank Balance Sheets: Sensitivity Tests

\begin{tabular}{|c|c|c|c|c|c|c|}
\hline & $\begin{array}{c}1 \\
\text { Neighbor }\end{array}$ & $\begin{array}{c}5 \\
\text { Neighbors }\end{array}$ & $\begin{array}{l}\text { Matching } \\
\text { variables }\end{array}$ & $\begin{array}{c}\text { Control } \\
\text { countries }\end{array}$ & $\begin{array}{l}\text { Belgium } \\
\text { only }\end{array}$ & Placebo \\
\hline \multicolumn{7}{|c|}{ Panel A : ratio of liquid assets to total assets (LIQ) } \\
\hline \multirow[t]{2}{*}{ LB } & -2.62 & -2.63 & -2.63 & -1.16 & -1.16 & -2.34 \\
\hline & $(4.28)$ & $(4.28)$ & $(4.28)$ & $(1.88)$ & $(1.88)$ & $(3.28)$ \\
\hline \multirow[t]{2}{*}{ DB } & -2.03 & -5.13 & -4.87 & -1.23 & -1.12 & -4.27 \\
\hline & $(3.24)$ & $(6.03)$ & $(6.73)$ & $(1.63)$ & $(1.32)$ & $(6.83)$ \\
\hline \multirow[t]{2}{*}{ LB $x$ DB } & $0.02 * *$ & $0.05 * *$ & $0.05 * *$ & $0.03 * *$ & $0.03 * *$ & 0.03 \\
\hline & $(0.01)$ & $(0.02)$ & $(0.02)$ & $(0.02)$ & $(0.02)$ & $(0.05)$ \\
\hline Bank fixed effects & Yes & Yes & Yes & Yes & Yes & Yes \\
\hline County-Year fixed effects & Yes & Yes & Yes & Yes & Yes & Yes \\
\hline Observations & 135 & 418 & 309 & 147 & 83 & 309 \\
\hline R-squared & 0.70 & 0.57 & 0.81 & 0.73 & 0.80 & 0.56 \\
\hline \multicolumn{7}{|c|}{ Panel B : ratio of mandatory reserves to total assets (RES) } \\
\hline \multirow[t]{2}{*}{ LB } & 0.11 & 0.16 & 0.11 & 0.07 & 0.07 & 0.11 \\
\hline & $(0.17)$ & $(0.27)$ & $(0.17)$ & $(0.15)$ & $(0.15)$ & $(0.17)$ \\
\hline \multirow[t]{2}{*}{ DB } & -0.05 & -0.04 & -0.05 & -0.04 & -0.04 & -0.05 \\
\hline & $(0.08)$ & $(0.06)$ & $(0.08)$ & $(0.08)$ & $(0.08)$ & $(0.08)$ \\
\hline \multirow[t]{2}{*}{ LB x DB } & $-0.11 * *$ & $-0.11 * *$ & $-0.11 * *$ & $-0.07 * *$ & $-0.07 * *$ & -0.04 \\
\hline & $(0.06)$ & $(0.07)$ & $(0.05)$ & $(0.05)$ & $(0.05)$ & $(0.05)$ \\
\hline Bank fixed effects & Yes & Yes & Yes & Yes & Yes & Yes \\
\hline Country-Year fixed effects & Yes & Yes & Yes & Yes & Yes & Yes \\
\hline Observations & 132 & 418 & 309 & 147 & 83 & 309 \\
\hline R-squared & 0.62 & 0.64 & 0.74 & 0.63 & 0.81 & 0.65 \\
\hline \multicolumn{7}{|c|}{ Panel $\mathrm{C}$ : ratio of securities to total assets (SECU) } \\
\hline \multirow[t]{2}{*}{ LBR } & 3.11 & 3.21 & 3.03 & 1.22 & 1.23 & 3.16 \\
\hline & $(5.03)$ & $(5.20)$ & $(4.73)$ & $(0.93)$ & $(0.93)$ & $(5.03)$ \\
\hline \multirow[t]{2}{*}{ DB } & $6.18^{* *}$ & $6.26 * *$ & $6.13 * *$ & $4.28 * *$ & $4.18 * *$ & $6.12 * *$ \\
\hline & $(3.81)$ & $(3.81)$ & $(3.70)$ & $(2.81)$ & $(2.81)$ & $(3.71)$ \\
\hline \multirow[t]{2}{*}{ LBR $\times$ DB } & $0.15^{* *}$ & $0.18^{* *}$ & $0.16^{* *}$ & $0.15^{* *}$ & $0.18^{* *}$ & 0.13 \\
\hline & $(0.09)$ & $(0.08)$ & $(0.07)$ & $(0.09)$ & $(0.09)$ & $(0.27)$ \\
\hline Bank fixed effects & Yes & Yes & Yes & Yes & Yes & Yes \\
\hline Country-Year fixed effects & Yes & Yes & Yes & Yes & Yes & Yes \\
\hline Observations & 134 & 418 & 309 & 147 & 83 & 309 \\
\hline R-squared & 0.52 & 0.61 & 0.70 & 0.61 & 0.61 & 0.54 \\
\hline
\end{tabular}


Table 10 - Impact of LBR on Bank Balance Sheets: Sensitivity Tests (continued)

\begin{tabular}{|c|c|c|c|c|c|c|}
\hline & $\begin{array}{c}1 \\
\text { Neighbor }\end{array}$ & $\begin{array}{c}5 \\
\text { Neighbors }\end{array}$ & $\begin{array}{c}\text { Matching } \\
\text { variables }\end{array}$ & $\begin{array}{c}\text { Control } \\
\text { countries }\end{array}$ & $\begin{array}{l}\text { Belgium } \\
\text { only }\end{array}$ & Placebo \\
\hline \multicolumn{7}{|c|}{ Panel D : ratio of total equity (to total assets (EQUITY) } \\
\hline \multirow[t]{2}{*}{ LB } & $-0.41 * *$ & $-0.59 * *$ & $-0.51 * *$ & $-0.09 * *$ & $-0.09 * *$ & $-0.59 * *$ \\
\hline & $(0.26)$ & $(0.26)$ & $(0.26)$ & $(0.06)$ & $(0.06)$ & $(0.26)$ \\
\hline \multirow[t]{2}{*}{ DB } & $-1.90 * *$ & $-1.90 * *$ & $-1.8 * *$ & $-0.78 * *$ & $-0.78 * *$ & $-1.8 * *$ \\
\hline & $(1.18)$ & $(1.21)$ & $(1.11)$ & $(0.48)$ & $(0.48)$ & $(1.11)$ \\
\hline \multirow[t]{2}{*}{ LB x DB } & $1.19 * *$ & $1.29 * *$ & $1.31 * *$ & $0.59 * *$ & $0.59 * *$ & 1.01 \\
\hline & $(0.71)$ & $(0.79)$ & $(0.80)$ & $(0.36)$ & $(0.36)$ & $(1.52)$ \\
\hline Bank fixed effects & Yes & Yes & Yes & Yes & Yes & Yes \\
\hline County-Year fixed effects & Yes & Yes & Yes & Yes & Yes & Yes \\
\hline Observations & 135 & 418 & 309 & 147 & 83 & 309 \\
\hline R-squared & 0.79 & 0.75 & 0.67 & 0.71 & 0.83 & 0.76 \\
\hline \multicolumn{7}{|c|}{ Panel E : ratio of total customers' deposits to total assets (CUSTD) } \\
\hline \multirow[t]{2}{*}{ LB } & -1.13 & -1.54 & -1.64 & -0.81 & -0.78 & -1.68 \\
\hline & $(1.82)$ & $(2.39)$ & $(2.63)$ & $(1.39)$ & $(1.37)$ & $(2.39)$ \\
\hline \multirow[t]{2}{*}{ DB } & $2.13 * * *$ & $2.10 * * *$ & $1.96 * *$ & $0.90 * * *$ & $0.90 * * *$ & $2.10 * * *$ \\
\hline & $(0.80)$ & $(0.78)$ & $(1.18)$ & $(0.78)$ & $(0.78)$ & $(0.78)$ \\
\hline \multirow[t]{2}{*}{ LB x DB } & $0.73 * * *$ & $0.71 * *$ & $0.68 * *$ & $0.85 * *$ & $0.88 * *$ & $0.78 *$ \\
\hline & $(0.24)$ & $(0.24)$ & $(0.39)$ & $(0.52)$ & $(0.54)$ & $(0.69)$ \\
\hline Bank fixed effects & Yes & Yes & Yes & Yes & Yes & Yes \\
\hline Country-Year fixed effects & Yes & Yes & Yes & Yes & Yes & Yes \\
\hline Observations & 134 & 418 & 309 & 147 & 83 & 309 \\
\hline R-squared & 0.73 & 0.78 & 0.83 & 0.69 & 0.69 & 0.81 \\
\hline \multicolumn{7}{|c|}{ Panel F : ratio of total banks' deposits to total assets (BANKD) } \\
\hline \multirow[t]{2}{*}{ LBR } & 0.17 & 0.17 & 0.17 & 0.05 & 0.07 & 0.17 \\
\hline & $(0.25)$ & $(0.25)$ & $(0.25)$ & $(0.08)$ & $(0.11)$ & $(0.25)$ \\
\hline \multirow[t]{2}{*}{ DB } & $-2.76 * * *$ & $-3.16 * * *$ & $-3.12 * * *$ & $-3.66 * *$ & $-3.66 * *$ & $-3.12 * * *$ \\
\hline & $(1.80)$ & $(1.95)$ & $(1.90)$ & $(2.28)$ & $(2.28)$ & $(1.80)$ \\
\hline \multirow[t]{2}{*}{ LBR x DB } & $1.17 * *$ & $1.17 * *$ & $1.01 * *$ & $1.42 * *$ & $1.47 * *$ & 0.73 \\
\hline & $(0.81)$ & $(0.81)$ & $(0.71)$ & $(0.91)$ & $(0.91)$ & $(0.96)$ \\
\hline Bank fixed effects & Yes & Yes & Yes & Yes & Yes & Yes \\
\hline Country-Year fixed effects & Yes & Yes & Yes & Yes & Yes & Yes \\
\hline Observations & 134 & 418 & 309 & 147 & 83 & 309 \\
\hline R-squared & 0.62 & 0.64 & 0.74 & 0.63 & 0.51 & 0.56 \\
\hline
\end{tabular}


Table 10 - Impact of LBR on Bank Balance Sheets: Sensitivity Tests (continued)

\begin{tabular}{|c|c|c|c|c|c|c|}
\hline & $\begin{array}{c}1 \\
\text { Neighbor }\end{array}$ & $\begin{array}{c}5 \\
\text { Neighbors }\end{array}$ & $\begin{array}{l}\text { Matching } \\
\text { variables }\end{array}$ & $\begin{array}{c}\text { Control } \\
\text { countries }\end{array}$ & $\begin{array}{l}\text { Belgium } \\
\text { only }\end{array}$ & Placebo \\
\hline \multicolumn{7}{|c|}{ Panel G : log of total assets (SIZE) } \\
\hline \multirow[t]{2}{*}{ LBR } & $0.25 * * *$ & $0.25 * * *$ & $0.25 * * *$ & $0.07 * * *$ & $0.07 * * *$ & $0.25 * * *$ \\
\hline & $(0.09)$ & $(0.09)$ & $(0.09)$ & $(0.03)$ & $(0.03)$ & $(0.09)$ \\
\hline \multirow[t]{2}{*}{ DB } & $0.56^{*}$ & $0.86^{*}$ & $0.86^{*}$ & $1.72 *$ & $1.69 *$ & $0.86^{*}$ \\
\hline & $(0.28)$ & $(0.68)$ & $(0.68)$ & $(1.25)$ & $(1.18)$ & $(0.67)$ \\
\hline \multirow[t]{2}{*}{ LBR $x$ DB } & $0.08 * *$ & $0.06 * *$ & $0.06 * *$ & $0.11 * *$ & $0.11 * *$ & 0.03 \\
\hline & $(0.05)$ & $(0.04)$ & $(0.04)$ & $(0.08)$ & $(0.08)$ & $(0.04)$ \\
\hline Bank fixed effects & Yes & Yes & Yes & Yes & Yes & Yes \\
\hline Country-Year fixed effects & Yes & Yes & Yes & Yes & Yes & Yes \\
\hline Observations & 134 & 418 & 309 & 147 & 83 & 309 \\
\hline R-squared & 0.82 & 0.64 & 0.74 & 0.63 & 0.81 & 0.67 \\
\hline
\end{tabular}

The table analyses the sensitivity of the results regarding the impact of LBR on the banks' balance sheets to variations in the matching procedure and false timing of the introduction of the LBR (placebo test). The first four columns address the matching procedure while the last column reports the results of a placebo test. Regarding the matching procedure, we consider respectively the closest neighbor as the matched bank for each Dutch bank and the nearest five neighbors. Next, we add some bank-specific variables in the estimation of the propensity score and finally, we restrict the countries from which to select the banks to be included in the control group. Firstly, we consider Belgium and Luxembourg as they form with the Netherlands the BENELUX economic union and secondly, given the specific nature of banking in Luxembourg, we restrict the sample to Belgium and the Netherlands. The effect of the LBR is captured by the coefficient of "LBRxDB". Standard errors are clustered at the bank level. *, **,*** indicate significance at the $10 \%, 5 \%$, and $1 \%$ levels, respectively.

Table 11 - LBR and Implicit Interest Rate on Bank Deposits

\begin{tabular}{lc}
\hline & IMPLICIT \\
\hline LBR & $-0.37^{*}$ \\
& $(0.22)$ \\
DB & $0.18^{*}$ \\
& $(0.13)$ \\
LBRxDB & 1.14 \\
& $(1.65)$ \\
Bank fixed effects & Yes \\
Country-Year fixed effects & Yes \\
\hline Observations & 418 \\
R-squared & 0.67 \\
\hline
\end{tabular}

The table analyses the impact of the LBR on bank deposit implicit interest rates measured as the ratio of interest expense on deposits to total deposits in a difference-in-difference set up. The sample consists of banks from The Netherlands and the matched non-Dutch banks over the 2000- 2006 period. The effect of the LBR is captured by the coefficient of "LBRxDB". Standard errors are clustered at the bank level. *, **, *** indicate significance at the $10 \%, 5 \%$, and $1 \%$ levels, respectively. 